\title{
RESOURCES
}

"Direct Marketing Resource Notebook," produced by the Midwest Sustainable Agriculture Working Group, is $\$ 20$ from Nebraska Sustainable Agriculture Society, P.O. Box 736, Hartington, NE 68739; (402) 254-2289. Nebraska residents should add $5 \%$ sales tax.

"Alternative Farming Systems-Economic Aspects, March 1993-June 1996," a bibliography, is available from Alternative Farming Systems Information Center, National Agricultural Library, 10301 Baltimore Ave., Room 304, Beltsville, MD 20705-2351; (301) 504-6559; e-mail afsic@nal.usda.gov; Internet-http:/www.nal.usda.gov/afsic.

"New Partnerships for Sustainable Agriculture," 148 pages, is $\$ 14.95$ plus $\$ 3.50$ shipping from World Resources Institute Publications, P.O. Box 4852, Hampden Station, Baltimore, MD 21211; 1-800-822-0504 or (410) 516-6963; e-mail ChrisD@wri.org.

"Integrated Animal Waste Management," 87 pages, is $\$ 20$ from Council for Agricultural Science and Technology, 4420 West Lincoln Way, Ames, IA 50014; 1-800375-CAST

"The Case of Organic Farming: Research Implications for a Paradigm Shift in Agriculture" is available for $\$ 20$ from Centre for Resource and Environmental Studies, Australian National University, Canberra ACT 0200 Australia; phone (06) 249-4598; e-mail publications@cres.anu.edu.au; Internet-http://cres.anu.edu.au.
"Knee Deep in Grass," a study of 29 grazing operations published by the Minnesota Institute for Sustainable Agriculture, is $\$ 7$ (\$7.35 in Minnesota) for item BU-6693-NR from Minnesota Extension Service Distribution Center, $1-800-876-8636$ or (612) 642-4900.

"Direct Marketing Resource Notebook" from the Midwest Sustainable Agriculture Working Group is $\$ 20$ from the Nebraska Sustainable Agriculture Society, P.O. Box 736, Hartington, NE 68739; (402) 254-2289; Nebraska residents must add $5 \%$ sales tax.

"Beekeeping in Northern Climates," a manual and 40-minute video (EP-6684$\mathrm{NR}$ ), are $\$ 45$ plus shipping and tax; manual alone (MI-6683-NR)is \$15; the video (VH6553-NR), \$40; contact Minnesota Extension Service Distribution Center, 1-800$876-8636$ or (612) 624-4900.

"IPMnet" is a free, global, collaborative, electronic Integrated Pest Management information source; for information, e-mail IMPnetNUZ@bcc.orst.edu.

“1996 CSA Farm Network" is \$6 from Steve Gilman, Coordinator, CSA Farm Network, 130 Ruckytucks Farm, Stillwater, N.Y. 12170; (518) 583-4613.

"Organic Production: Recent Publications and Current Information Sources" is available from Alternative Farming Systems Information Center, National Agricultural Library, ARS, USDA, Room 304, 10301 Baltimore Ave., Beltsville, MD
20705-2351; (301) 504-6559; or on the Internet at http://www.nal.usda.gov.afsic

"Becoming Native to this Place," six essays by Wes Jackson, is available for $\$ 12.50$ from Publishers Group West, P.O. Box 8843, Emeryville, CA 94662; 1-800-788-3123.

"Noah's Ark Today: Saving Rare Farm Animal Breeds from Extinction," a children's education program, contains a slide program, activities for K-6th grade, and a teacher's guide; each kit is $\$ 119$ plus $\$ 11$ shipping/ handling from Carolyn Christman, American Livestock Breeds Conservancy, P.O. Box 477, Pittsboro, N.C. 27312; (919) 542-5704.

International Short Course on Agroecology will be offered at the Center for Biological Control at the University of California, Berkeley, June 16-25, 1997; for application, contact Dr. Miguel Altieri, University of California, 201 Wellman Hall-3112; Berkeley, CA 94720; e-mail agroeco3@nature.berkeley.edu; fax (510) 642-7428.

"Organic Agriculture Worldwide 19961997" is \$16 from IFOAM, Okozentrum Imsbach, D-66636 Tholey-Theley/Germany; e-mail ifoam secretary@oln.comlink.apc.org.

Proceedings of the North American Symposium of the Association for Farming Systems Research/Extension, held in November, 1995, are $\$ 15$, payable to NCRCRD, from Julie Stewart, North Central Regional Center for Rural Development, 404 East Hall, Iowa State University, Ames, IA 50011.

\section{UPCOMING EVENTS}

February 17-18, Great Lakes Grazing Conference will be held in Battle Creek, MI; contact Ben Bartlette, MSU Extension, U.P. Experiment Station, Box 168, Chatham, MI 49816-0160; (906) 439-5880.

February 18-20, New York State Farmers' Direct Marketing Conference and Trade Show will be held in Owego, N.Y.; contact Andrea Eichhorn, Conference Chair, (607) 862-3985.

February 18-21, "Sensors for Nondestructive Testing: Measuring the Quality of Fresh Fruits and Vegetables" will be held in Orlando,
FL; contact Northeast Regional Agricultural Engineering Service, Cooperative Extension, 152 Riley-Robb Hall, Ithaca, N.Y. 14853-5701; (607) 255-7654; e-mail NRAES@comell.edu.

February 21-22, "Grow Better, Not Bigger," the Annual Meetings of the Nebraska Sustainable Agriculture Society and Nebraska Fruit and Vegetable Growers, will be held in Columbus, NE; contact NSAS, (402) 254-2289.

February 23-25, 14th annual California Farm Conference will be held in Riverside, CA; contact Mary Lou Weiss, University of
California, (310) 781-7520; or UC Small Farm Center, (916) 752-8136.

February 24-25, "Charting a New Course," the Agricultural Outlook Forum '97 sponsored by the USDA, will be held in Washington, D.C.; contact USDA Graduate School, 600 Maryland Ave., SW, Room 142 (IH), Washington, D.C. 20024; (202) 401-9421.

February 27-March 2, Bio Fach '97, the World Organic Show, will be held in Frankfurt, Germany; contact Sunder \& Rottner, Von-Vollmar-Str.4, D-91154 Roth; phone (+49) 09171/4011. 